\title{
A DESCRIPTIVE STUDY TO ASSESS THE AWARENESS REGARDING SILICOSIS AND ITS PREVENTION AMONG QUARRY WORKERS AT JODHPUR, WITH A VIEW TO DEVELOP INFORMATION BOOKLET
}

\author{
Parvej Khan \\ M.sc. Nursing,Medical Surgical Nursing-Critical care, Mai Khadija Institute of Nursing Sciences, \\ Jodhpur, Rajasthan
}

Article DOI: https://doi.org/10.36713/epra4607

\begin{abstract}
Introduction- Silicosis is one of the oldest occupational lung disease, which is incurable and is caused by inhalation of dust containing free crystalline silica. Silicosis is preventable disease. Still this disease kills thousands of workers around the worlds every year. Various studies have should that the quarry workers due not having awareness regarding silicosis and its prevention. In this study, distribution of booklet among quarry workers is an attempt to improve the knowledge regarding silicosis and it/s prevention.

Material and Methods - Quantitative descriptive survey study approach and non experimental research design was used.Total 100 quarry workers working in mining and residing in Jodhpur were selected by purposive sampling technique.Data collection by structured knowledge questionnaire and analysed by using descriptive and inferential statistics.

Result - The findings of the study reveals that to the level of awareness shows that majority (52\%) of the sample had above average, followed by $48 \%$ had below average awareness regarding silicosis and its prevention. However, demographic variables age and educational status indicates significant association with the level of awareness regarding silicosis and its prevention.

Conclsion - The awareness of quarry workers regarding silicosis and its prevention have been above average regarding the causes and the management of the silicosis but in regarding the symptoms and prevention of the silicosis have been found below the average level.
\end{abstract}

KEY WORDS - Awareness, Quarry Workers, Silicosis, Information Booklet 


\section{SJIF Impact Factor: 7.001| ISI I.F.Value:1.241| Journal DOI: 10.36713/epra2016 ISSN: 2455-7838(Online)}

EPRA International Journal of Research and Development (IJRD)

\section{INTRODUCTION}

Silicosis is a well-known fibro genic lung disease which is probably one of the oldest occupational diseases known to man. Recognized since ancient times, this incurable lung disease caused by inhalation of dust containing free crystalline silica. It is irreversible and the disease progresses even when exposure stops. Silicosis is preventable. However, it continues to pose a very real threat to some people on a daily basis and still kills thousands around the world every year.

Silica causes disease when workers breathe in tiny silica particles released into the air with the dust created by cutting, grinding, drilling or blasting rocks. The particles are so small they can only be seen with a microscope, but they are so light that they can remain airborne for a long time. Silica can therefore travel long distances in the air and affect populations not otherwise considered to be at risk.

In India, there are about 3 million workers formally employed in the formal economy with potential exposure to silica dust. Further, approximately 8.5 million more work in construction and many more in the informal economy with exposure to silica dust. Thousands of these workers develop silicosis every year and die directly from it, or from secondary causes such as TB or lung cancer. However, relatively few of these deaths are recorded as being caused by silicosis or as being work-related in national statistics. Reliable statistics are not available for India, but there are many industries where exposures to silica dust are known to exist. Because Silicosis is difficult to detect in its early stages because of the absence of symptoms.

Rajasthan is the second biggest resource in mineral wealth in India after Bihar. A large number of mines of various minerals are found in the state. An estimate suggests that nearly 2 million people are engaged in the industry of mining in state. Mine workers have a long history of difficult work conditions and exploitation and discrimination.

Western Rajasthan especially Jodhpur and Makrana are famous for its sand stone mines and marble mines. Sand stone produced from these mines is used extensively for the construction of beautiful buildings. However, the miners who work very hard to make this stone available live a life full of agony, misery and pain. Their problems die with them in complete silence of big mines.

Silicosis is an untreatable, but preventable disease. Awareness and planning are keys to prevention of silicosis. Ensuring that workers are aware of the dangers of breathing in silica dust and by providing them with the correct equipment, protective gear and properly ventilated working environments, the worldwide elimination of silicosis as an occupational health problem by the year 2030 is achievable.

\section{MATERIAL AND METHODS}

For the study, a descriptive design was adopted as it is a virtue of a situation that naturally happens. In many aspects of nursing there is a need for a clear picture or description of the phenomena before causality can be examined.A quantitative descriptive design was adopted in the study. The population consisted of CHC Hospital and Mining Area Fidusar at Jodhpur. A sample size of 100 quarry workers was selected using purposive sampling. A structure questionnaire was adopted by the investigator for data collection. The tool structured knowledge questionnaire is validated by experts. Reliability of the tool was done using Karl Pearson (Co-relation, co-efficient) formula.

\section{RESULT}

The analysis and interpretation of data collected from 100 quarry workers working in mines at Jodhpur to assess the awareness regarding silicosis and its prevention. Descriptive and inferential statistics were used for analysis. It was found that mean awareness level of the quarry workers is above average and mean score and SD of awareness was found is $14.42 \pm 2.923$. However, the majority of the demographic variables such as gender, marital status, religion, household income, age of starting work, type of work, working experience in mines, and working hours per day were found not significant association with the level of awareness regarding silicosis and its prevention except age and educational status.

Table No. 1 shows that majority (52\%) of the sample had above average, followed by $48 \%$ had below average awareness regarding silicosis and its prevention. 


\section{EPRA International Journal of Research and Development (IJRD)}

Volume: 5 | Issue: 6 | June 2020

- Peer Reviewed Journal

Table No. 1

Frequency and percentage distribution of the level of awareness regarding silicosis and its prevention. $(\mathrm{N}=100)$

\begin{tabular}{|c|c|c|}
\hline Level of Awareness & Frequency & Percentage \\
\hline Below Average & 48 & $48 \%$ \\
\hline Above Average & 52 & $52 \%$ \\
\hline
\end{tabular}

Table No. 2 shows that the awareness score of quarry workers according to the different aspects of the silicosis and its prevention was highest (83\%) regarding the 'causes of silicosis' with the mean 2.49 and $\mathrm{SD}$ of \pm 0.674 , followed by $72 \%$ regarding the 'management of the silicosis' with the mean 3.60 and $\mathrm{SD}$ of $\pm 1.054,71.67 \%$ regarding 'silica production' with the mean 2.15 and SD of $\pm 0.821,69.17 \%$ regarding 'prevention of silicosis' with the mean 4.15 and $\mathrm{SD}$ of \pm 1.192 and lowest $(67.67 \%)$ in regarding 'symptoms of silicosis' with the mean 2.03 and SD of \pm 0.758 . The overall awareness score with mean $\pm \mathrm{SD}$ is $14.42 \pm 2.923$ and mean percent awareness of $72.10 \%$.

Table No. 2

Aspects wise mean awareness score regarding silicosis and its prevention.

$(\mathrm{N}=100)$

\begin{tabular}{|c|c|c|c|c|}
\hline Awareness Aspects & Maximum & Mean & 土S.D. & Mean \% \\
\hline Causes of Silicosis & 3 & 2.49 & 0.674 & $83.00 \%$ \\
\hline Symptoms of silicosis & 3 & 2.03 & 0.758 & $67.67 \%$ \\
\hline Silica Production & 3 & 2.15 & 0.821 & $71.67 \%$ \\
\hline Management of silicosis & 5 & 3.60 & 1.054 & $72.00 \%$ \\
\hline Prevention of silicosis & 6 & 4.15 & 1.192 & $69.17 \%$ \\
\hline Overall & $\mathbf{2 0}$ & $\mathbf{1 4 . 4 2}$ & $\mathbf{2 . 9 2 3}$ & $\mathbf{7 2 . 1 0 \%}$ \\
\hline
\end{tabular}

\section{CONCLUSION}

After the detailed analysis, this study gives the following conclusion

1. The majority $(52 \%)$ of samples were aware about the silicosis \&its prevention.

2. Insignificant association between the awareness of samples with selected sociodemographic variables like Gender, Marital status, Religion, Household income, Type of work, Working experience in mines, Working hours per day except Age, Educational status,

3. According to Age of the samples, older were more aware than the adult.

4. According to Educational status of the samples, more educated workers are more aware regarding silicosis and its prevention then less educated workers.

\section{REFERENCS}

1. Luton Tina, Silicosis: educate Eliminate Eradicate. Best practice. 2007;(12) [cited 2017 Mar 31]. Available from: http://www.indianet.nl/pdf/silicosis.pdf

2. Chong S, Lee KS, Chung MJ, Han J, Kwon OJ, Kim TS. Pneumoconiosis: comparison of imaging and pathologic, Radio graphics. 2006; 26:5977.

3. Rimal B, Greenberg AK, Rom WN. Basic pathogenetic mechanisms in silicosis: current understanding. Curr Opin Pulm Med. 2005;11:169-73

4. Balaan MR, Banks DE. Silicosis. In: Rom WM (ed). Environmental and Occupational Medicine, 3rd Edition. Philadelphia, Lippincott-Rave Publishers, 1998: 435-48

5. Silicosis - Silica Dust Exposure \& Prevention [cited 2017 Mar 31]. Available from:http://www.silicosis.com/exposure/index /php

6. MIA Technical Module - Silicosis: An Industry Guide to Awareness and Prevention [Internet]. Marble Institute of America; 2008 
[cited 2017 Mar 31]. Available from: http://www.marble-institute.com/ default/ assets/ File/ news /Silicosis Industry_ Guide_ Tech_Module_2008.pdf

7. Occupational Knowledge International. Legislative Provisions Relating to Silica Exposure and Silicosis in India: The Need for Review [Internet]. 2009 [cited 2017 Apr 25] p. 3-4. Available from: http://www. Ok international. org/docs/Silica\%20Legislative\%20Review.pdf

8. Davis GS. The pathogenesis of silicosis. State of the art. Chest. 1986;89166S-9S.

9. Article related to Silicosis. [homepage on the Internet]. 2011 [cited 2017 mar 31]. Available from: http://www.en.wikipedia.org

10. Article related to complications of Silicosis and their prevention. [homepage on the Internet]. 2011 [cited 2017 mar 31]. Available from: http://www. en.wikipedia.org

11. Article related to Air sampling and prevention of Silicosis. [homepage on the Internet]. 2011 [cited 2017 mar 31]. Available from: http://www.en. Wikipedia.org

12. Yadav SP, Anand pk, Singh," Awareness \& practices about silicosis among the sandstone quarry workers in desert ecology of Jodhpur Rajasthan, India” 2011,J Hum Ecol,33(3);191-196

13. Shah B. Involvement of lung and lung function tests in stone quarry workers. Indian journal of Tuberculosis [homepage on the Internet]. 2011 [cited 2017 Apr 19]. Available from: http://www.ncbi.nlm.gov/pubmed.com.

14. What is review of literature/Royal Literary Fund,3 Johnson's Court off Fleet Street London EC4A 3EA Available from https ://www. rlf.org.uk /home/ contact-us/ 